\title{
Production optimization and characterization of immunomodulatory peptides obtained from fermented goat placenta
}

\author{
Yinchen HOU ${ }^{1}$, Wangwang LIU $^{1}$, Yongxia CHENG ${ }^{1}$, Jiejing ZHOU ${ }^{1}$, Li WU ${ }^{1}$, Gongming YANG ${ }^{1 *}$
}

\begin{abstract}
The goat placental immunomodulatory peptides were produced by fermentation with Aspergillus Niger. The objective of the present study was to investigate the effects of fermentation parameters (carbon source content, $\mathrm{pH}$, and time) on spleen lymphocyte proliferation for the highest immune activity of the fermentation broth using response surface methodology (RSM). According to the data analysis by the Design-Expert ${ }^{\circledR}$ software, the stimulation index value $(23.51 \%)$, which is the maximum immune activity, was obtained under the following conditions: content of carbon source $1.97 \mathrm{~g} \cdot \mathrm{L}^{-1}$, initial $\mathrm{pH} \mathrm{5.0}$, and $74.43 \mathrm{~h}$ of fermentation time. Under the optimized fermentation conditions, at a certain concentration range, the fermentation broth produced a significant effect on the proliferation of mouse spleen lymphocytes. Ultrafiltration technique was performed to separate the fermentation broth with different MW (molecular weight). It was found that peptides in the range of $<10 \mathrm{KDa}$ were the main bioactivity fractions for the immunomodulatory and antioxidant activities.
\end{abstract}

Keywords: Aspergillus Niger; goat placenta; immune modulation; antioxidant; bioactive peptide.

\section{Introduction}

Bioactive peptides play an important role in metabolic regulation and modulation, including antioxidant, antihypertensive, antimicrobial and immunomodulatory activities (Anyogu et al., 2014; Kim \& Wijesekara, 2010; Korhonen \& Pihlanto, 2006; Zheng et al., 2014). Immunomodulatory peptides can enhance immune cell functions such as lymphocyte proliferation, natural killer (NK) cell activity, antibody synthesis, and cytokine regulation (Singh et al., 2014). Many immunomodulatory peptides have been isolated from enzymatic digests of various food proteins such as those found in fish, soy, and whey (Halldorsdottir et al., 2014; Kong et al., 2008; Saint-Sauveur et al., 2008).

Goat placenta has long been used in Oriental medicine for the treatment of physiological abnormalities in human organs, and recent studies have demonstrated that it is a rich source of biological and therapeutic compounds (Chakraborty \& Bhattacharyya, 2005; Chakraborty et al., 2006; Park et al., 2010; Teng et al., 2011). Although numerous activities of goat placental peptides have been reported so far, studies have not been reported on the immune active peptides prepared by fermentation.

Basically, bioactive peptides can be prepared from precursor proteins in multiple ways, including enzymatic hydrolysis and microbial fermentation (Zhang et al., 2014). Microbial fermentation is one of the most important sources of enzyme production. Therefore, microbial fermentation could be used as a source of proteolytic enzymes that can effectively hydrolyze proteins to prepare peptides (He et al., 2012). Various peptides with antioxidant and ACE-inhibitory activity are derived from rapeseed, whey protein, milk and peanut meal and are prepared by microbial fermentation (He et al., 2012; Otte et al., 2011; Pan \& Guo, 2010; Zhang et al., 2014). In this study, the goat placental peptides with immune and antioxidant activity were prepared by fermentation with Aspergillus Niger.

The objective of the present study was to investigate the effects of fermentation parameters on spleen lymphocyte proliferation for the highest immune activity of the fermentation broth using response surface methodology (RSM). The mixture of immune-active peptides prepared under the optimal conditions was separated with ultrafiltration (UF) and the immune activity and antioxidant capacity of most effective fraction were determined.

\section{Materials and methods}

\subsection{Materials and chemicals}

Goat placenta was obtained from ewes at parturition and preserved by freezing at $-45{ }^{\circ} \mathrm{C}$ (immersion freezing). A freeze-dried culture of Aspergillus Niger was kindly donated by Henan University of Technology; 6-8 week-old female BALB/c mice were purchased from the laboratory animal center of the Southern Medical University. All experimental procedures were carried out in accordance with standard guidelines for the care of animals and approved by the Welfare Committee of the Centre of Experimental Animal, Guangzhou, China.

Concanavalin A (Con A), lipopolysaccharides (LPS), and 3 - (4,5 - dimethylthiazol - 2 - yl) - 2, 5-diphenyltetrazolium bromide (MTT) were purchased from Sigma Chemical Co., USA. RPMI-1640 and Fetal Bovine Serum (FBS) were obtained from Gibco Co., USA. Filtering centrifuge tube was purchased 
from Millipore Co., USA. All other reagents used in this study were of analytical grade.

\subsection{Preparation of pre-cultures}

The Aspergillus Niger strain with high protease activity was reanimated and maintained on a nutrient agar slope at $4{ }^{\circ} \mathrm{C}$. The inoculum was prepared by adding a loopful of cells to $100 \mathrm{ml}$ of sterile culture medium, which contained $30 \mathrm{~g} \cdot \mathrm{L}^{-1}$ glucose, 20 $\mathrm{g} \cdot \mathrm{L}^{-1}$ peptone, $2 \mathrm{~g} \cdot \mathrm{L}^{-1} \mathrm{MgSO}_{4}, 1 \mathrm{~g} \cdot \mathrm{L}^{-1} \mathrm{~K}_{2} \mathrm{HPO}_{4}$ and $2 \mathrm{~g} \cdot \mathrm{L}^{-1} \mathrm{KH}_{2} \mathrm{PO}_{4}$ at $\mathrm{pH} 5.5$, which was then incubated in an air-bath rotary shaker for $36 \mathrm{~h}$ at $30^{\circ} \mathrm{C}$ and rotation speed $2.84 \times \mathrm{g}$.

\subsection{Preparation of fermentation material}

In order to protect the activity of protein in the production process, liquid nitrogen is added into the beating process of goat placentas to reduce temperature. After the beating process, the goat placentas were homogenized with physiological saline(five times the weight of goat placentas), the mixture was stirred for 4 hours at $20^{\circ} \mathrm{C}$. The water-soluble immune-active peptides were extracted by centrifugation at $4000 \times \mathrm{g}$, and the precipitate was used as fermentation material.

\subsection{Fermentation experiments}

The microbial cells were harvested in their exponential phase and were transferred into the peptide production medium, which contained $1 \mathrm{~g} \cdot \mathrm{L}^{-1} \mathrm{CaCl}_{2}, 1 \mathrm{~g} \cdot \mathrm{L}^{-1} \mathrm{NH}_{4} \mathrm{Cl}, 2 \mathrm{~g} \cdot \mathrm{L}^{-1}$ $\mathrm{Na}_{2} \mathrm{HPO}_{4}$, and $25 \mathrm{~g} \cdot \mathrm{L}^{-1}$ goat placenta solids. Glucose was used as the carbon source with the concentrations ranging from 1 to $3 \mathrm{~g} \cdot \mathrm{L}^{-1}$. The $\mathrm{pH}$ varied between 4 and 6 , and the fermentation time varied from $60 \mathrm{~h}$ to $80 \mathrm{~h}$. The other conditions were the same as the pre-culture conditions. Each experiment was conducted in triplicate.

\subsection{Optimization of fermentation conditions}

The fermentation conditions, including the initial content of glucose $\left(\mathrm{x}_{1}\right)$ and fermentation time $\left(\mathrm{x}_{2}\right), \mathrm{pH}$ of culture media $\left(\mathrm{x}_{3}\right)$, were optimized for the immune activity of the fermentation broth using a Central Composite design. A Central Composite design with three factors and one block and 20 runs was used in this study (Ren et al., 2008).

The Central Composite design contained three levels for each process parameter coded as $-1,0$, and +1 . The central design was applied based on three different content of glucose $\left(1 \mathrm{~g} \cdot \mathrm{L}^{-1}, 2 \mathrm{~g} \cdot \mathrm{L}^{-1}, 3 \mathrm{~g} \cdot \mathrm{L}^{-1}\right)$, three different fermentation times ( $60 \mathrm{~h}, 70 \mathrm{~h}, 80 \mathrm{~h})$, and initial $\mathrm{pH}(\mathrm{pH} 4.0, \mathrm{pH} 5.0, \mathrm{pH} 6.0)$. The pre-cultured Aspergillus Niger cells were inoculated into $10 \%(\mathrm{w} / \mathrm{v})$ reconstituted fermentation medium (adjusted to the experimental design $\mathrm{pH}$ ). These mixtures were incubated at the designated temperature and time. All experiments were conducted in triplicate according to the experimental design (Table 1). The second-order polynomial equation was used to express the stimulus index $(\mathrm{Y})$. Functions of the independent variables are as follows (Equation 1):

$$
\mathrm{Y}=b_{0}+\sum_{i=1}^{3} b_{i} X_{i}+\sum_{i=1}^{3} b_{i i} X_{i}^{2}+\sum_{i=1}^{2} \sum_{j=i+1}^{3} b_{i j} X_{i} X_{j}+e_{i}
$$

Where $\mathrm{Y}$ is the response variable; $\mathrm{b}_{0}$ is the constant coefficient (intercept); $b_{i}$ is the linear coefficient (main effect); $b_{\mathrm{ii}}$ is the quadratic coefficient; $b_{i j}$ is the two factors interaction coefficient, and $e_{i}$ is the random error.

Table 1. Experimental values for the optimization of the fermentation conditions by RSM.

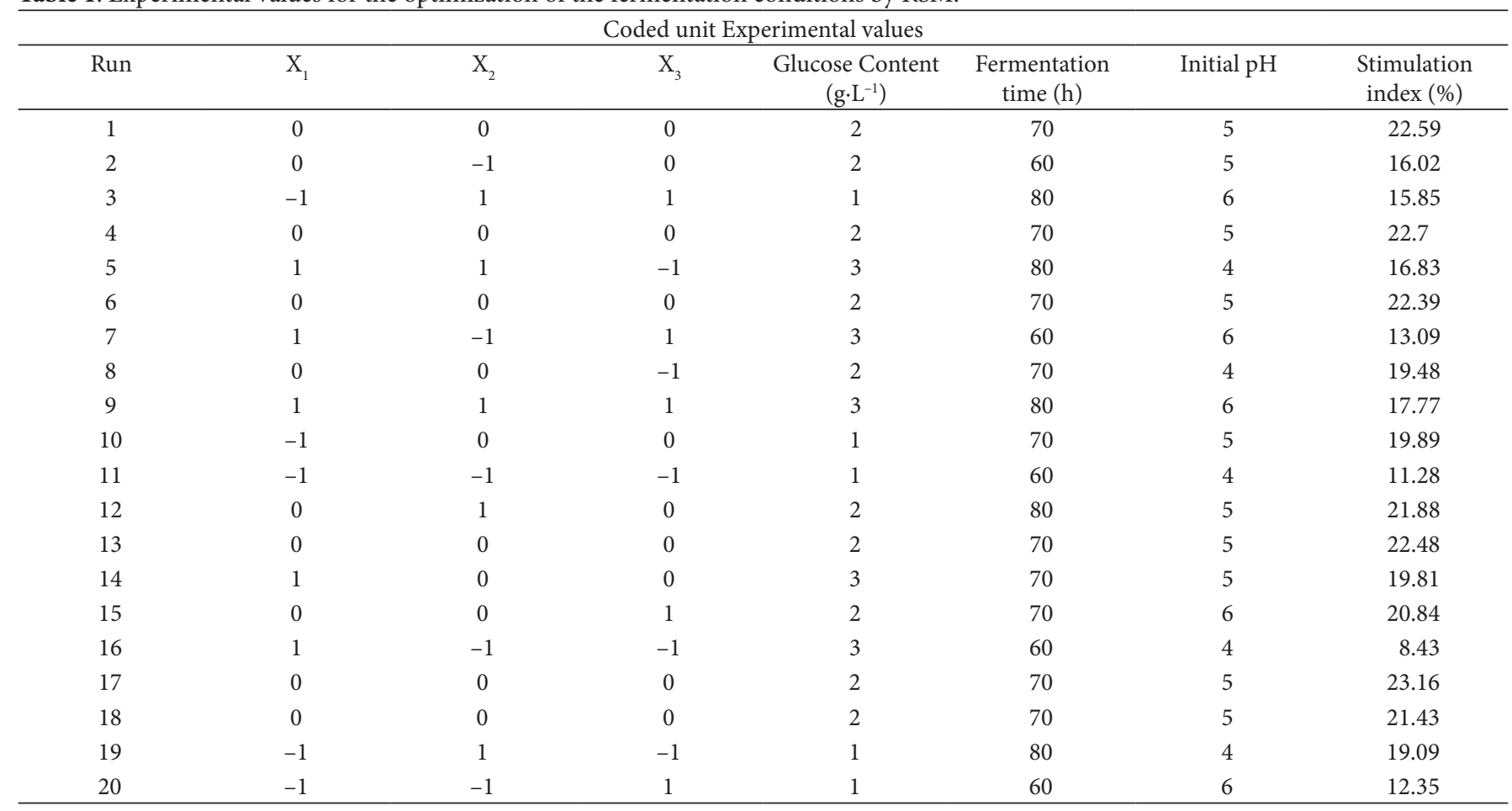




\subsection{Splenocyte preparation}

Immunomodulation activity of the fermentation broth was evaluated by measuring their effect on spleen lymphocytes proliferation in vitro (Hou et al., 2012). The splenocytes were isolated from 6-8 week-old female BALB/c mice. The mice were sacrificed by cervical dislocation. The spleens were removed and placed in individual sterile culture dishes containing $3 \mathrm{~mL}$ of RPMI-1640 medium under aseptic conditions. The splenocytes were dissociated by gently pressing the organ through a 200 mesh cell strainer. The cells suspension was collected in sterile $15 \mathrm{ml}$ conical tubes and centrifuged $(135 \times \mathrm{g})$ at room temperature for $8 \mathrm{~min}$. The pellets were resuspended in $6 \mathrm{~mL}$ of $0.87 \% \mathrm{NH}_{4} \mathrm{Cl}$ to remove erythrocytes by osmotic shock. One minute later, twice the volume of the RPMI medium was added to stop the reaction. The mononuclear cell suspension prepared was washed twice with RPMI and centrifuged at $111 \times \mathrm{g}$ for 8 min. Cell viability was assessed by the trypan blue exclusion method. The cell suspension was then adjusted to $2 \times 10^{6}$ viable cells/mL in RPMI medium (Bao et al., 2002; Yuan et al., 2009).

\subsection{Splenocyte lymphocyte proliferation assay}

Splenocyte lymphocyte proliferation was determined by the MTT colorimetric assay method (Hou et al., 2012). The cells were added to 96-well flat-bottom plates and treated with the fermentation broth at the same concentrations. Control wells received the same volume of the RPMI medium. The effect of the fermentation broth and the co-effect of that with Con A and LPA were also evaluated in the same experiments. The microplates with and without Con A and LPA were incubated at $37{ }^{\circ} \mathrm{C}$ under $5 \% \mathrm{CO}_{2}$ atmosphere at $90 \%$ relative humidity for $48 \mathrm{~h}$. MTT $(20 \mu \mathrm{l}$ of $5 \mathrm{mg} / \mathrm{ml})$ was added to each well of the multiwell plates, and the plates were incubated for another $4 \mathrm{~h}$ period under the same conditions. Next, the plates were centrifuged at $1000 \mathrm{~g}$ for $8 \mathrm{~min}$, and the medium was removed. Finally, dimethyl sulfoxide was added to each well, and the plates were agitated on a plate shaker for $10 \mathrm{~min}$. Absorbance was determined at $570 \mathrm{~nm}$ using a PerkinElmer Victor1420 micro plate reader. Data were expressed as a stimulation index (SI) and were calculated using in the following Equations 2 and 3:

\section{SI (without Con A and LPA)}

$\mathrm{SI}=\frac{\text { Fluorescence }_{\text {cellstsample }}-\text { Control }_{\text {cells }}}{\text { Control }_{\text {cells }}}$

SI (with Con A or LPA)

$\mathrm{SI}=\frac{\text { Fluorescence }_{\text {cells }+ \text { sample }+ \text { ConA or LPA }}-\text { Control }_{\text {cells }}}{\text { Control }_{\text {cells }}}$

\subsection{Scavenging effect on DPPH free radical}

The DPPH radical-scavenging capacity assay of goat placental peptides was carried out using a previously method (Blois, 1958) with minor modification. Briefly, the sample $(0.5 \mathrm{~mL})$ was mixed with $2.5 \mathrm{~mL}$ of distilled water and $3 \mathrm{~mL}$ $0.2 \mathrm{mM}$ DPPH in ethanol and kept for $30 \mathrm{~min}$ in the dark at room temperature. The absorbance of the resulting solution was measured at $517 \mathrm{~nm}$ against a blank control. Ethanol was used to calibrate the spectrophotometer. The DPPH radical-scavenging capacity was calculated as follows (Equation 4):

DPPH radical scavenging capacity $(\%)$

$$
=\left(1-\frac{A b s_{\text {sample }}-A b s_{\text {sample control }}}{A b s_{\text {blank }}}\right) \times 100
$$

Where $\mathrm{Abs}_{\text {sample }}$ is the absorbance of the sample with DPPH solution; $\mathrm{Abs}_{\text {samplecontrol }}$ is the absorbance of the sample without $\mathrm{DPPH}$ solution; and $\mathrm{Abs}_{\text {blank }}$ is the absorbance of the distilled water and the DPPH solution.

\subsection{Preparation of peptide fractions}

Amicon filters with different MW were used to separate goat placenta peptides. All recovered fractions (fractions from above $100 \mathrm{KDa}, 50 \mathrm{KDa}$ to $100 \mathrm{KDa}, 30 \mathrm{KDa}$ to $50 \mathrm{KDa}, 10 \mathrm{KDa}$ to $30 \mathrm{KDa}, 3 \mathrm{KDa}$ to $10 \mathrm{KDa}$, and below $3 \mathrm{KDa}$ ) were dissolved to the initial volume in water. The immune and antioxidant activity were measured according the methods described above.

\subsection{Statistical analysis}

The stimulation index determinations and the antioxidant assays were conducted in three replicates, and the data were expressed as mean \pm standard deviation (SD). A one-way analysis of variance (ANOVA) was conducted for the analysis of the response values obtained by the RSM model.

\section{Results and discussion}

\subsection{Optimization of the hydrolysis conditions by RSM}

RSM was used to optimize the fermentation conditions for the preparation of goat placenta bioactivity peptides. The influence of glucose content, fermentation time, and initial $\mathrm{pH}$ on the spleen lymphocyte proliferation of the fermentation broth was shown in Table 1. Statistical analysis of the response surface model is shown in Table 2. The p value shows that the model was significant and could be used to monitor the optimization of the hydrolysis conditions $(\mathrm{p}<0.0001)$. Among the three independent variables, the $\mathrm{p}$ value of fermentation time was less than 0.0001, which indicates that the fermentation time was the variable with the highest significance level. The effect of initial $\mathrm{pH}$ had the most significant effect within a $99 \%$ confidence interval ( $p=0.0064<0.01)$. However, the effect of glucose content was not significant $(\mathrm{p}=0.1000>0.05)$. Therefore, it was concluded that fermentation time and initial $\mathrm{pH}$ had a greater significant effect on the spleen lymphocyte proliferation of the fermentation broth as compared with that of the glucose content. The quadratic terms, $\mathrm{X}_{1} \cdot \mathrm{X}_{1}, \mathrm{X}_{2} \cdot \mathrm{X}_{2}$ and $\mathrm{X}_{3} \cdot \mathrm{X}_{3}(\mathrm{p}<0.05)$ and the interaction terms $\mathrm{X}_{1} \cdot \mathrm{X}_{3}, \mathrm{X}_{2} \cdot \mathrm{X}_{3}(\mathrm{p}<0.01)$ were also significant.

The following empirical regression (Equation 5) represents the stimulation index $(\mathrm{Y})$ of the fermentation broth as a function of glucose content $\left(\mathrm{X}_{1}\right)$, fermentation time $\left(\mathrm{X}_{2}\right)$, and initial $\mathrm{pH}$ $\left(\mathrm{X}_{3}\right)$. The ANOVA for the response surface quadratic model is shown in Table 2.

$\mathrm{Y}=22.42-0.25 \times \mathrm{X}_{1}+3.02 \times \mathrm{X}_{2}+0.48 \times \mathrm{X}_{3}+0.22 \times \mathrm{X}_{1} \times \mathrm{X}_{2}+$

$0.97 \times X_{1} \times X_{3}-1.00 \times X_{2} \times X_{3}-2.50 \times X_{1}^{2}-3.40 \times X_{2}^{2}-2.19 \times X_{3}^{2}$ 
Preparation, bioactivity of peptides

Table 2. Statistical analysis for the response surface quadratic model of the RSM design.

\begin{tabular}{|c|c|c|c|c|c|}
\hline Source & Sum of Squares & $\mathrm{df}$ & Mean Square & F Value & $\mathrm{P}$ \\
\hline Model & 352.3192966 & 9 & 39.14658851 & 200.8935556 & $<0.0001^{* *}$ \\
\hline A-content of glucose (\%) & 0.64009 & 1 & 0.64009 & 3.284831728 & 0.1000 \\
\hline B-fermentation time & 91.50625 & 1 & 91.50625 & 469.5943278 & $<0.0001^{* *}$ \\
\hline C-initial pH & 2.29441 & 1 & 2.29441 & 11.77451728 & $0.0064^{* *}$ \\
\hline $\mathrm{AB}$ & 0.3916125 & 1 & 0.3916125 & 2.009687958 & 0.1867 \\
\hline $\mathrm{AC}$ & 7.5466125 & 1 & 7.5466125 & 38.72791667 & $<0.0001^{* *}$ \\
\hline $\mathrm{BC}$ & 8.0601125 & 1 & 8.0601125 & 41.3631103 & $<0.0001^{* *}$ \\
\hline $\mathrm{A}^{2}$ & 17.21250909 & 1 & 17.21250909 & 88.33163458 & $<0.0001^{* *}$ \\
\hline $\mathrm{B}^{2}$ & 31.82400909 & 1 & 31.82400909 & 163.3153381 & $<0.0001^{* *}$ \\
\hline $\mathrm{C}^{2}$ & 13.21118409 & 1 & 13.21118409 & 67.79752326 & $<0.0001^{* *}$ \\
\hline Residual & 1.948623409 & 10 & 0.194862341 & & \\
\hline Lack of Fit & 0.317940076 & 5 & 0.063588015 & 0.194973524 & 0.9515 \\
\hline Pure Error & 1.630683333 & 5 & 0.326136667 & & \\
\hline Total & 354.26792 & 19 & & & \\
\hline R-squared & 0.9945 & & & & \\
\hline Adj R-squared & 0.9895 & & & & \\
\hline Pred R-squared & 0.9856 & & & & \\
\hline Adeq precision & 45.008 & & & & \\
\hline
\end{tabular}

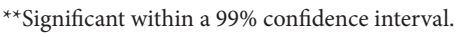

The ANOVA analysis for the model (Table 2) showed that the "lack of fit" was not significant $(\mathrm{p}=0.9515>0.05)$, indicating that the model indeed represented the actual relationships of fermentation parameters. The F-value of the model was 200.89, which indicates that the model is significant. Values of "Prob > F" less than 0.0500 indicate that the model terms are significant. The "Pred R-Squared" of 0.9856 is in reasonable agreement with the "Adj R-Squared" of 0.9895. "Adeq Precision" measures the signal to noise ratio; a ratio greater than 4 is desirable. Adeq Precision of 45.008 indicates an adequate signal showing that this model can be used to navigate the design space.

To determine the optimal levels of each variable for immune activity peptide production, three-dimensional response surface plots were constructed by plotting the response (stimulation index of fermentation broth) on the $\mathrm{Z}$-axis against any two independent variables, while maintaining other variables at their optimal levels (Figure 1). As shown in Figure 1, there is a close relationship between the stimulation index and initial $\mathrm{pH}$ or glucose content. Excessively high and low content of glucose or initial $\mathrm{pH}$ led to a decrease in the stimulation index. When initial $\mathrm{pH}$ or glucose content was similar to that of the medium, the stimulation index increased. Fermentation time had a positive linear effect on the stimulation index. However, the negative quadratic effect became significant during long time fermentation.

\subsection{Optimization and model validation}

According to the data analysis by the Design-Expert ${ }^{\circledR}$ software, the highest stimulation index value of $23.51 \%$ was obtained under the following conditions: fermentation time of $74.43 \mathrm{~h}$, initial $\mathrm{pH}$ value of 5.00 , and glucose content of $1.97 \%$. To confirm the model validity, three assays were performed under the optimal conditions. Comparative analysis of the predicted value and experimental values using paired t-test indicated no significant $(p<0.01)$ difference between the two values, thereby establishing validity of the generated model.

\subsection{Immune activity of fermentation broth}

The immunoactivity effect of the fermentation broth was evaluated in vitro by measuring its effect on lymphocyte proliferation. As shown in Figure 2, the stimulation index commonly associated with immune activity increased in a concentration dependent way. The stimulation index increased quickly from the concentration of $6.25 \mathrm{mg} / \mathrm{mL}$ to $100 \mathrm{mg} / \mathrm{mL}$, and at the concentration of $6.25-100 \mathrm{mg} / \mathrm{mL}$; the stimulation index of the fermentation broth showed a good linear relationship with a linear $\mathrm{R}^{2}$ of 0.991 . Then, the stimulation index increased gradually with the increase in concentration of $100-200 \mathrm{mg} / \mathrm{mL}$, in agreement with enzymatic hydrolysates of Alaska Pollock frame according to the study reported by Hou et al. (2012). These results suggested that the fermentation broth might act as a mitogen for murine splenic lymphocytes.

\subsection{Effect of fermentation broth with Con A or LPS on spleen lymphocyte proliferation}

Well-known as T-cell and B-cell mitogens, Con A and LPS are used as the positive control, markedly stimulated the proliferation of murine splenic lymphocytes. The effects of the fermentation broth with different concentration on lymphocytes proliferation were evaluated in stimulated cells (with mitogens, Con A or LPS), as shown in Figure 3. The fermentation broth had the synergistic activity with Con A and LPS. At the concentration of $6.25-25 \mathrm{mg} / \mathrm{mL}$, the synergistic effect of the fermentation broth with Con A was better than that of LPS; however, at the concentration of $50-200 \mathrm{mg} / \mathrm{mL}$, contrary results were obtained. 

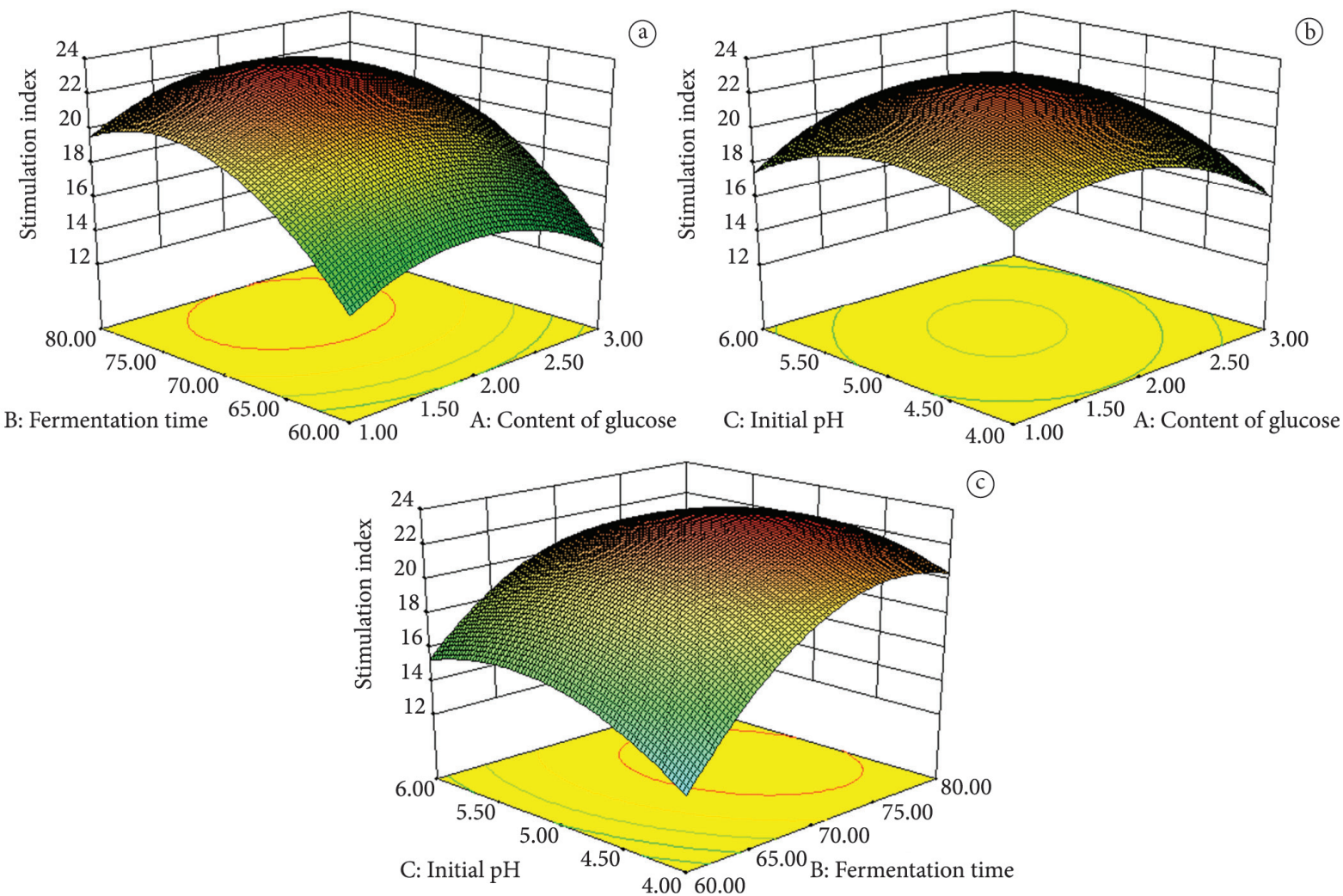

Figure 1. Response-surface plots for the effect of variables on immune activity: (a) Glucose Content (A) and fermentation time (B). The initial $\mathrm{pH}(\mathrm{C})$ was set at the centre of its level viz. 6.0; (b) Glucose Content (A) and initial pH (C). Fermentation time (B) was set at the centre of itslevel viz. 70h; (c) fermentation time (B) and initial $\mathrm{pH}(\mathrm{C})$. Glucose Content (A) was set at the centre of its level viz. $2 \%$.

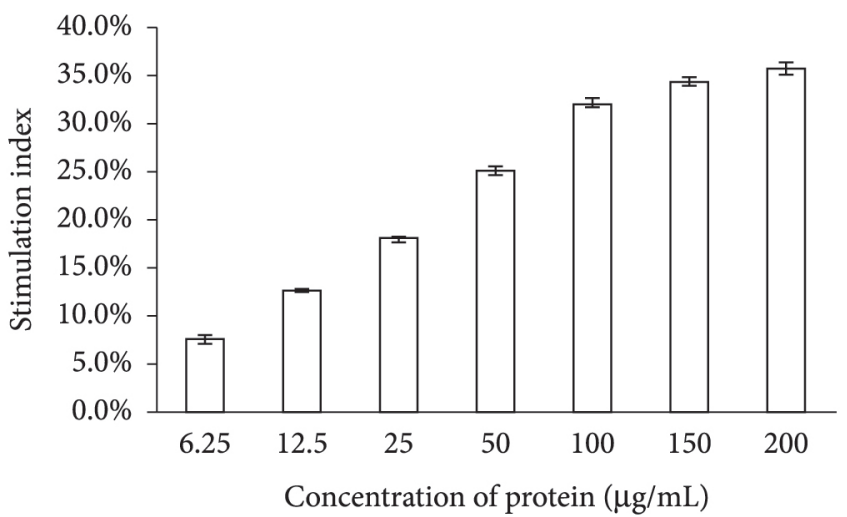

Figure 2. Effect of fermentation broth with different protein concentrations on spleen lymphocyte proliferation.

\subsection{Fractionation of fermentation broth and its bioactivity}

Ultrafiltration technique was performed to separate the fermentation broth with different MW. As shown in Table 3, the fermentation broth obtained at optimum parameters was then fractioned into six fractions. It was found that peptides in the range of $3 \mathrm{KDa}-10 \mathrm{KDa}$ were the main bioactivity fractions for the immune activity and peptides in the range of $3 \mathrm{~K}-10 \mathrm{KDa}$, and $<3 \mathrm{KDa}$ showed the highest antioxidant activity. Immunoregulatory peptides in the range of $3 \mathrm{KDa}-10 \mathrm{KDa}$ extracted from goat placenta could enhance humoral immunity

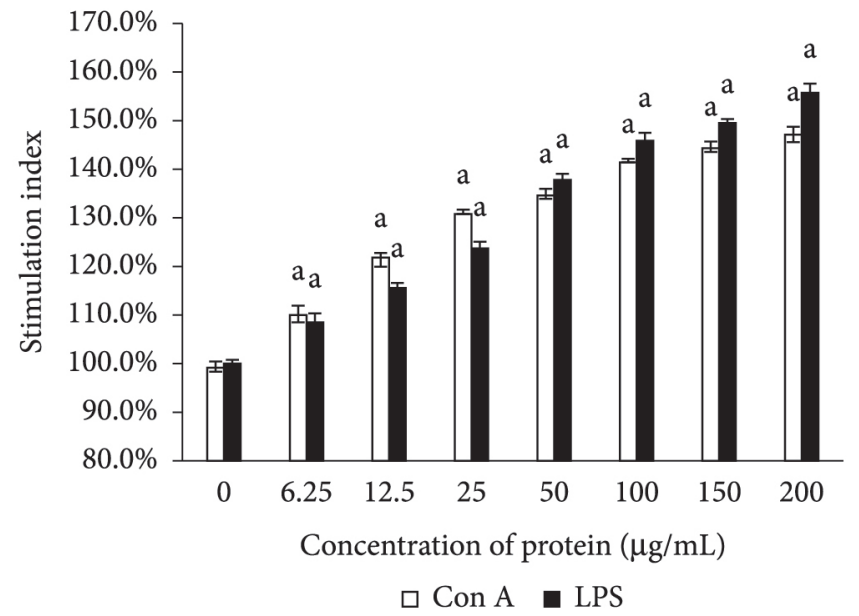

Figure 3. Effect of the fermentation broth with LPS and Con A on spleen lymphocyte proliferation. The concentration of LPS or Con A was $10 \mathrm{mg} / \mathrm{mL}$; each value is expressed as mean \pm SD of 6 separate experiments; $\mathrm{P}$ values are shown as ${ }^{\mathrm{a}} \mathrm{p}<0.05$, ${ }^{\text {aa }} \mathrm{p}<0.01$ compared with those of the control group.

function and recover the ability of humoral immunity in mice with immunodeficiency (Liaoqiong et al., 2005). Bezerra et al. (2013) demonstrated that the activity level was higher in permeate peptides $(<3 \mathrm{KDa})$ than in retentate peptides $(>3 \mathrm{KDa})$. These authors used ultrafiltration technique to evaluate the 
influence of peptides molar mass molecular weight on biological activities. The analyzed peptides were present in caprine casein hydrolysates, which were obtained by papain enzyme use.

There is a certain correlation between the bioactivity of goat placental peptides and its MW. It is recognized that, due to their lower molecular mass, peptides can be more reactive than those with higher MW (Korhonen \& Pihlanto, 2006), and the bioactivity of peptides is also related to their space structure, the characteristics of precursor proteins, and restricted enzyme sites. This finding is in agreement with those of previous studies which support the fact that the bioactivity of peptides is related to molecular mass (Cian et al., 2012; Kim et al., 2007; Pan \& Guo, 2010; Teng et al., 2011; Tsai et al., 2008; Zhou et al., 2012).

\section{Conclusion}

Goat placental protein was effectively fermented using Aspergillus Niger to obtain peptides with strong immunoactivity. It was shown that a second-order polynomial model was sufficient to properly describe and predict the responses of immunoactivity of the fermentation broth. The linear term of fermentation time and initial $\mathrm{pH}$ and the quadric term of initial $\mathrm{pH}$ along with the interaction of fermentation time and glucose content significantly affected the immunoactivity of the fermentation broth. The stimulation index value for the fermentation broth increased with the increase in concentration of $6.25-200 \mathrm{mg} / \mathrm{mL}$. The fermentation broth had the synergistic activity with Con A and LPS. Peptides in the range of $<10$ $\mathrm{KDa}$ showed the highest immunoactivity and antioxidation. These results suggest that the fermentation broth might act as a mitogen for murine splenic lymphocytes.

\section{Acknowledgements}

This study was supported by the science and technology funds of Guangdong province (2009CD030).

\section{References}

Anyogu, A., Awamaria, B., Sutherland, J. P., \& Ouoba, L. I. I. (2014). Molecular characterisation and antimicrobial activity of bacteria associated with submerged lactic acid cassava fermentation. Food Control, 39(0), 119-127. http://dx.doi.org/10.1016/j. foodcont.2013.11.005.

Bao, X.-F., Wang, X.-S., Dong, Q., Fang, J.-N., \& Li, X.-Y. (2002). Structural features of immunologically active polysaccharides from Ganoderma lucidum. Phytochemistry, 59(2), 175-181. http://dx.doi. org/10.1016/S0031-9422(01)00450-2. PMid:11809453

Bezerra, V. S., Campos, J. F. C., Silva, R. A., Porto, T. S., Lima Filho, J. L., \& Porto, A. L. F. (2013). Biotechnological richness of the northeastern semi-arid region: antioxidant activity of casein hydrolysates from Moxotó goat milk (Capra hircus Linnaeus, 1758) obtained by papain action. Food Science and Technology (Campinas.), 33(3), 513-520. http://dx.doi.org/10.1590/S010120612013005000074.

Blois, M. S. (1958). Antioxidant Determinations by the Use of Stable Free Radical. Nature, 181, 1199-1200. http://dx.doi. org/10.1038/1811199a0.

Chakraborty, P. D., \& Bhattacharyya, D. (2005). Isolation of fibronectin type III like peptide from human placental extract used as wound healer. Journal of Chromatography. B, Analytical Technologies in the Biomedical and Life Sciences, 818(1), 67-73. http://dx.doi. org/10.1016/j.jchromb.2004.09.059. PMid:15722046

Chakraborty, P. D., Bhattacharyya, D., Pal, S., \& Ali, N. (2006). In vitro induction of nitric oxide by mouse peritoneal macrophages treated with human placental extract. International Immunopharmacology, 6(1), 100-107. http://dx.doi.org/10.1016/j.intimp.2005.07.018. PMid:16332518

Cian, R. E., Martínez-Augustin, O., \& Drago, S. R. (2012). Bioactive properties of peptides obtained by enzymatic hydrolysis from protein byproducts of Porphyra columbina. Food Research International, 49(1), 364-372. http://dx.doi.org/10.1016/j.foodres.2012.07.003.

Halldorsdottir, S. M., Sveinsdottir, H., Freysdottir, J., \& Kristinsson, H. G. (2014). Oxidative processes during enzymatic hydrolysis of cod protein and their influence on antioxidant and immunomodulating ability. Food Chemistry, 142(0), 201-209. http://dx.doi.org/10.1016/j. foodchem.2013.07.053. PMid:24001832

He, R., Ju, X., Yuan, J., Wang, L., Girgih, A. T., \& Aluko, R. E. (2012). Antioxidant activities of rapeseed peptides produced by solid state fermentation. Food Research International, 49(1), 432-438. http:// dx.doi.org/10.1016/j.foodres.2012.08.023.

Hou, H., Fan, Y., Li, B., Xue, C., Yu, G., Zhang, Z., \& Zhao, X. (2012). Purification and identification of immunomodulating peptides from enzymatic hydrolysates of Alaska pollock frame. Food Chemistry, 134(2), 821-828. http://dx.doi.org/10.1016/j.foodchem.2012.02.186. PMid:23107696

Kim, S.-K., \& Wijesekara, I. (2010). Development and biological activities of marine-derived bioactive peptides: A review. J. Funct. Foods., 2(1), 1-9. http://dx.doi.org/10.1016/j.jff.2010.01.003.

Kim, S.-Y., Je, J.-Y., \& Kim, S.-K. (2007). Purification and characterization of antioxidant peptide from hoki (Johnius belengerii) frame protein by gastrointestinal digestion. The Journal of Nutritional Biochemistry, 18(1), 31-38. http://dx.doi.org/10.1016/j.jnutbio.2006.02.006. PMid:16563720

Kong, X., Guo, M., Hua, Y., Cao, D., \& Zhang, C. (2008). Enzymatic preparation of immunomodulating hydrolysates from soy proteins. Bioresource Technology, 99(18), 8873-8879. http://dx.doi. org/10.1016/j.biortech.2008.04.056. PMid:18524579

Korhonen, H., \& Pihlanto, A. (2006). Bioactive peptides: Production and functionality. International Dairy Journal, 16(9), 945-960. http:// dx.doi.org/10.1016/j.idairyj.2005.10.012.

Liaoqiong, F., Zhang, Z. Y., Niu, H., \& Wei, R. (2005). Influence on humoral immunity in mice by goat placenta immunoregulatory factor. Journal of Chongqing Medical University, 30(03), 356-358.

Otte, J., Lenhard, T., Flambard, B., \& Sørensen, K. I. (2011). Influence of fermentation temperature and autolysis on ACE-inhibitory activity and peptide profiles of milk fermented by selected strains of Lactobacillus helveticus and Lactococcus lactis. International Dairy Journal, 21(4), 229-238. http://dx.doi.org/10.1016/j. idairyj.2010.12.008.

Pan, D., \& Guo, Y. (2010). Optimization of sour milk fermentation for the production of ACE-inhibitory peptides and purification of a novel peptide from whey protein hydrolysate. International Dairy Journal, 20(7), 472-479. http://dx.doi.org/10.1016/j. idairyj.2010.01.007.

Park, S. Y., Phark, S., Lee, M., Lim, J. Y., \& Sul, D. (2010). Anti-oxidative and anti-inflammatory activities of placental extracts in benzo[a] pyrene-exposed rats. Placenta, 31(10), 873-879. http://dx.doi. org/10.1016/j.placenta.2010.07.010. PMid:20708262 
Ren, J., Zhao, M., Shi, J., Wang, J., Jiang, Y., Cui, C., Kakuda, Y., \& Xue, S. J. (2008). Optimization of antioxidant peptide production from grass carp sarcoplasmic protein using response surface methodology. LWT-. Food Science and Technology (Campinas.), 41(9), 1624-1632.

Saint-Sauveur, D., Gauthier, S. F., Boutin, Y., \& Montoni, A. (2008). Immunomodulating properties of a whey protein isolate, its enzymatic digest and peptide fractions. International Dairy Journal, 18(3), 260-270. http://dx.doi.org/10.1016/j.idairyj.2007.07.008.

Singh, B. P., Vij, S., \& Hati, S. (2014). Functional significance of bioactive peptides derived from soybean. Peptides, 54, 171-179. http://dx.doi. org/10.1016/j.peptides.2014.01.022. PMid:24508378

Teng, D., Fang, Y., Song, X., \& Gao, Y. (2011). Optimization of enzymatic hydrolysis parameters for antioxidant capacity of peptide from goat placenta. Food and Bioproducts Processing, 89(3), 202-208. http://dx.doi.org/10.1016/j.fbp.2010.05.001.

Tsai, J.-S., Chen, T.-J., Pan, B. S., Gong, S.-D., \& Chung, M.-Y. (2008). Antihypertensive effect of bioactive peptides produced by proteasefacilitated lactic acid fermentation of milk. Food Chemistry, 106(2), 552-558. http://dx.doi.org/10.1016/j.foodchem.2007.06.039.
Yuan, C., Huang, X., Cheng, L., Bu, Y., Liu, G., Yi, F., Yang, Z., \& Song, F. (2009). Evaluation of antioxidant and immune activity of Phellinus ribis glucan in mice. Food Chemistry, 115(2), 581-584. http://dx.doi. org/10.1016/j.foodchem.2008.12.055.

Zhang, Y., Liu, J., Lu, X., Zhang, H., Wang, L., Guo, X., Qi, X., \& Qian, H. (2014). Isolation and identification of an antioxidant peptide prepared from fermented peanut meal using bacillus subtilis fermentation. International Journal of Food Properties, 17(6), 12371253. http://dx.doi.org/10.1080/10942912.2012.675605.

Zheng, W., Zhao, T., Feng, W., Wang, W., Zou, Y., Zheng, D., Takase, M., Li, Q., Wu, H., Yang, L., \& Wu, X. (2014). Purification, characterization and immunomodulating activity of a polysaccharide from flowers of Abelmoschus esculentus. Carbohydrate Polymers, 106(0), 335-342. http://dx.doi.org/10.1016/j.carbpol.2014.02.079. PMid:24721087

Zhou, K., Sun, S., \& Canning, C. (2012). Production and functional characterisation of antioxidative hydrolysates from corn protein via enzymatic hydrolysis and ultrafiltration. Food Chemistry, 135(3), 1192-1197. http://dx.doi.org/10.1016/j.foodchem.2012.05.063. PMid:22953842 